\title{
Cistromics of hormone-dependent cancer
}

\author{
Mathieu Lupien ${ }^{1}$ and Myles Brown ${ }^{2,3}$ \\ ${ }^{1}$ Dartmouth Medical School, Norris Cotton Cancer Center, Lebanon, New Hampshire 03756, USA \\ ${ }^{2}$ Division of Molecular and Cellular Oncology, Department of Medical Oncology, Dana-Farber Cancer Institute, Boston, \\ Massachusetts 02115, USA \\ ${ }^{3}$ Department of Medicine, Brigham and Women's Hospital and Harvard Medical School, Boston, Massachusetts 02115, USA \\ (Correspondence should be addressed to M Brown; Email: myles_brown@dfci.harvard.edu)
}

\begin{abstract}
Alterations in transcription programs are a fundamental feature of cancer. Nuclear receptors, such as the estrogen receptor alpha (ER $\alpha$ ) and androgen receptors (ARs), are central in this process as they can directly impact gene expression through interaction with the chromatin and subsequent association with coregulators and the transcriptional machinery. Unbiased genome-wide investigations have demonstrated the predominant recruitment of both $\mathrm{ER} \alpha$ and AR to distant (non-promoter)-regulatory elements. Furthermore, these studies revealed a clear relationship between sites of transcription factor recruitment and gene regulation. Indeed, expression profiles from AR-positive primary prostate tumors and cell lines directly relate to the AR cistrome in prostate cancer cells, while the $\mathrm{ER} \alpha$ cistrome in breast cancer cells relates to expression profiles from $\mathrm{ER} \alpha$-positive primary breast tumors. Additionally, cell-type-specific ER $\alpha$ cistromes are linked to lineage-specific estrogen-induced expression profiles in different cell types, for example osteosarcoma and breast cancer cells. The pioneer factor forkhead box A1 (FoxA1/HNF3 $\alpha$ ) plays a central role in $A R$ and $E R \alpha$ signaling. It is recruited in a lineage-specific manner translating the epigenetic signature consisting of mono- and dimethylated histone $\mathrm{H} 3$ on lysine 4 (H3K4me1/me2) into functional regulatory elements. Hence, through the interplay between the pioneer factor, namely FoxA1, and epigenetic events, the transcriptional potential of a given cell lineage is predefined. Since this directly impacts signaling through nuclear receptors, these discoveries should significantly impact the development of novel therapeutic strategies directed against multiple types of cancer.
\end{abstract}

Endocrine-Related Cancer (2009) 16 381-389

\section{Characteristics of nuclear receptor cistromes}

Gene expression profiling of cancer has led to important new insights both in terms of classification and outcome. This is exemplified in breast cancer through studies where different subtypes of primary breast tumors have been identified (Sorlie et al. 2001, 2003), which also correspond to different disease/treatment outcomes (Sorlie et al. 2003). Similarly, prostate cancer development associates with transcriptional programs distinct from normal tissues (Welsh et al. 2001, Lapointe et al. 2004, Yu et al. 2004). Therefore, understanding the mechanisms that lead to these altered expression profiles is fundamental to the development of effective therapeutic intervention against cancers.

Nuclear receptors are central to the development of both breast and prostate cancer. The estrogen receptor alpha $(E R \alpha)$ is a fundamental feature of more than twothirds of breast cancers (Sorlie et al. 2001, 2003), while prostate cancer is highly dependent on the actions of the androgen receptor (AR; Heinlein \& Chang 2004). Both $\mathrm{ER} \alpha$ and $\mathrm{AR}$ are ligand-dependent transcription factors recruited directly to the chromatin through the estrogen-responsive elements (EREs) and androgenresponsive elements (AREs) respectively. They are also indirectly recruited to other genomic regions through a tethering mechanism involving other transcription factors such as AP-1 and Sp1 (Sanchez et al. 2002). Through their interplay with coregulators, $\mathrm{ER} \alpha$ and $\mathrm{AR}$ regulate the expression of genes central to breast and prostate cancer development, including CCND1, E2F1, Myc as well as TMPRSS2, and PSA respectively (Prall et al. 1998, Balk et al. 2003, Demichelis \& Rubin 2007, Stender et al. 2007, Frietze et al. 2008, Setlur et al. 2008). 
Recent technological advancements have allowed the mapping of the regulatory regions recruiting either directly or through tethering mechanisms these receptors on a genome-wide scale defining their cistromes (Lupien et al. 2008). Indeed, upon stimulation $\mathrm{ER} \alpha$ and $\mathrm{AR}$ are recruited to 1000 of sites in breast and prostate cancer cell lines respectively (Carroll et al. 2005, 2006, Lin et al. 2007, Wang et al. 2007, Hua et al. 2008, Hurtado et al. 2008, Liu et al. 2008, Lupien et al. 2008). These unbiased genomewide studies have revealed the preferential recruitment of both $\mathrm{ER} \alpha$ and $\mathrm{AR}$ with non-promoter-regulatory elements. This pattern of promoter-distant recruitment is also typical of other transcription factors in various systems such as forkhead box A1 (FoxA1), RelA (p65), NRSF, SRA, GABP, and many more (Carroll et al. 2006, Johnson et al. 2007, Lim et al. 2007, Lupien et al. 2008, Valouev et al. 2008). This contrasts with the distribution of other transcription factors such as E2F family members that are primarily recruited to promoters (Bieda et al. 2006, Xu et al. 2007). This highlights the complexity of the transcriptional response in higher order eukaryotes as regulatory elements can be found hundreds of kilobases $(\mathrm{kb})$ away from their target genes, but still be brought into promoter close proximity through chromosome looping (Dekker 2008). In fact, this process has been previously reported on a limited subset of ER $\alpha$ - and AR-binding sites for regions up to $140 \mathrm{~kb}$ away from the target gene (Carroll et al. 2005, Deschenes et al. 2007, Wang et al. 2007). Hence, a key milestone in transcriptional biology will consist of establishing the sum of all chromosome loops guiding transcriptional responses on a genome-wide scale.

\section{From nuclear receptor cistrome to transcription}

The comparison of nuclear receptor cistromes and hormone-regulated expression profiles reveals a clear relationship between the two. Indeed, genes overexpressed in ER $\alpha$-positive primary breast tumors as well as estrogen target genes in breast cancer cell lines are preferentially surrounded by estrogen-induced $\mathrm{ER} \alpha$-binding sites found in this same system (Carroll et al. 2006, Lupien et al. 2008, Fig. 1). Similarly, MCF7 cells overexpressing AKT induce a unique ER $\alpha$ cistrome that relates to the AKT-dependent expression profile (Bhat-Nakshatri et al. 2008, Fig. 1). This is also observed in osteosarcoma where the estrogeninduced $E R \alpha$ cistrome, distinct from the $E R \alpha$ cistrome in breast cancer cells, directly relates to the estrogen-induced expression profile in osteosarcoma
(Krum et al. 2008, Fig. 1). Furthermore, ER $\alpha$-binding sites cluster around these regulated genes (Krum et al. 2008). Similarly, the AR cistrome in androgendependent prostate cancer cells relates to the androgen-induced transcriptional program in these same cells as well as to the expression profile from primary prostate tumors (Wang et al. 2007, 2009, Lupien et al. 2008, Fig. 2). Furthermore, as prostate cancer cells become castration resistant following androgen-deprivation therapy, they acquire an altered expression program accompanied by a related novel AR cistrome (Wang et al. 2009). Hence, the capacity to establish specific cistromes under distinct activation and in different lineages is central to the implementation of transcriptional programs that define the nature of cellular identity.

\section{Coregulators central to nuclear receptor cistromes}

Through sequence analysis of regulatory regions recruiting either ER $\alpha$ or AR, conserved networks of regulatory factors have been defined (Carroll et al. 2005, 2006, Laganiere et al. 2005, Green \& Carroll 2007, Wang et al. 2007, Hurtado et al. 2008). Noteworthy, the GATA, OCT, PAX, NKX, and LEF motifs are significantly enriched near the center of ER $\alpha$ - and/or AR-binding sites. GATA3 recognizing the GATA motif was revealed to be part of a positive cross-regulatory loop with ER $\alpha$ in breast cancer cells required for the estrogen-mediated cell proliferation (Eeckhoute et al. 2007). In prostate cancer cells, GATA2 also recognizing the GATA motif was found to interact with AR and potentiates its regulation of target genes (Perez-Stable et al. 2000, Wang et al. 2007). Similarly, Oct-1 recognizing the OCT motif was shown to physically interact with $A R$ and its expression is required for AR-mediated transcriptional regulation in prostate cancer cells (Gonzalez \& Robins 2001, Wang et al. 2007). Furthermore, Oct-1 is co-recruited with $\mathrm{ER} \alpha$ in breast cancer cells regulating key target genes, namely CCND1 (Cicatiello et al. 2004, Carroll et al. 2006). More recently, PAX2 co-recruitment with $\mathrm{ER} \alpha$ to the ERBB2-regulatory element has revealed its central role as a transcriptional repressor required for inhibition of ERBB2 expression in breast cancer cells (Hurtado et al. 2008). Accordingly, loss of PAX2 recruitment allowed for ERBB2 expression in the presence of the anti-estrogen tamoxifen conferring anti-estrogen-resistant-like properties to normally anti-estrogen-sensitive breast cancer cells (Hurtado et al. 2008). Other factors such as LEF-1 and Nkx3-1 whose DNA recognition motif is enriched 


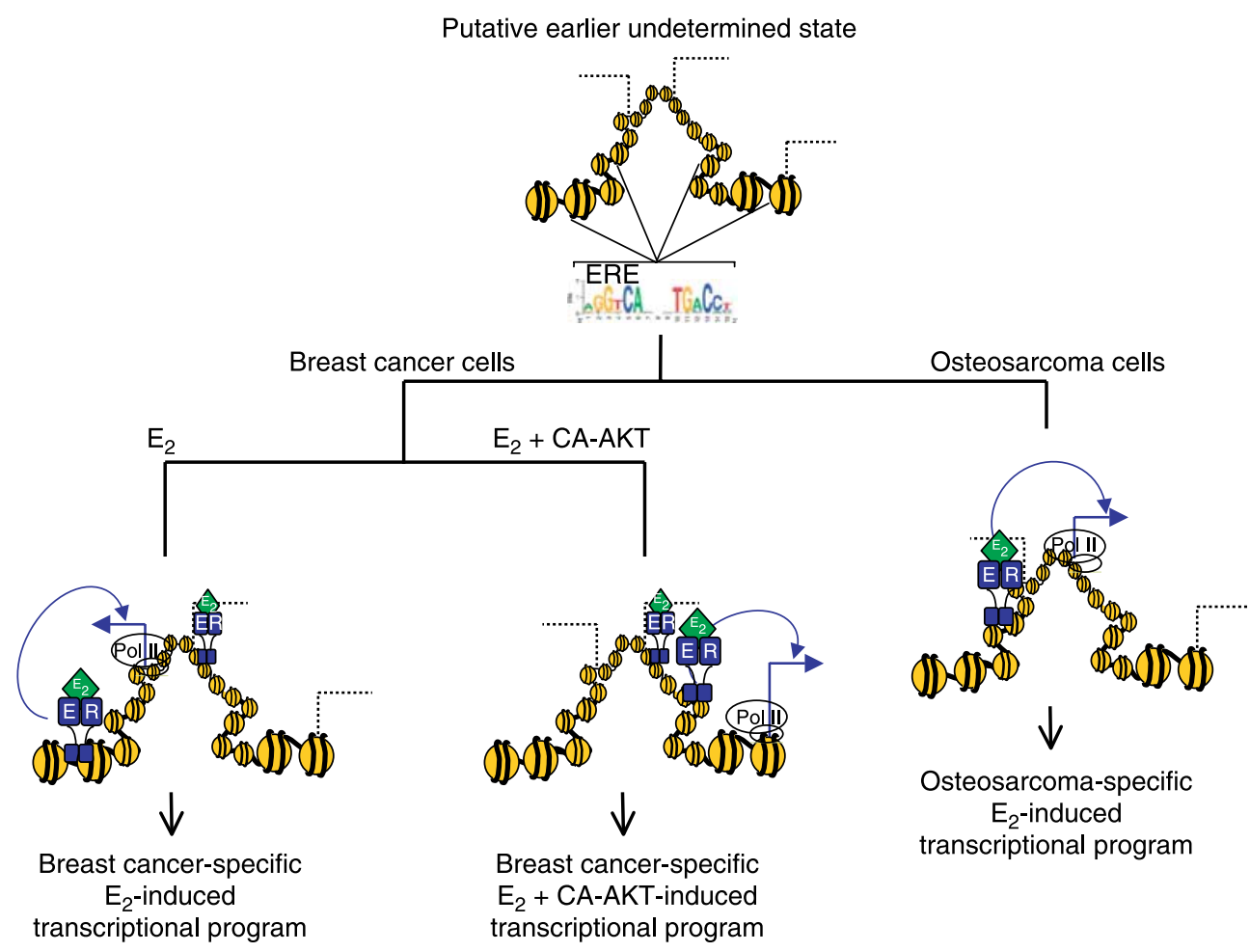

Figure 1 Lineage- and stimuli-specific transcriptional programs are dependent on differential recruitment of ER $\alpha$. Thousands of putative $\mathrm{ER} \alpha$-binding sites are found across the human genome. This includes over 60000 estrogen-responsive elements (EREs) and a number of regions recruiting $E R \alpha$ through a tethering mechanism. However, lineage-specific $E R \alpha$ recruitment, as reported between breast and osteosarcoma cancer cell lines, is central to the unique transcriptional program generated in each cell type following estrogen $\left(E_{2}\right)$ treatment. Similarly, the transcriptional program activated through the PI3K/AKT pathway in MCF7 cells expressing a constitutively active AKT (CA-AKT) is dependent on a unique ER $\alpha$ recruitment pattern.

in ER $\alpha$-binding sites in breast cancer cells behave in a distinct manner. Indeed, instead of being co-recruited with $\mathrm{ER} \alpha$ following estrogen stimulation, these transcription factors are bound at the basal state and block ER $\alpha$ recruitment abrogating estrogen growth-promoting properties (Holmes et al. 2008). Since LEF-1 and Nkx3-1 can associate with the histone deacetylase HDAC1, increased chromatin condensation is thought to be fundamental to block ER $\alpha$ recruitment (Holmes et al. 2008). Therefore, by defining the cistromes of $\mathrm{ER} \alpha$ and $\mathrm{AR}$, the intricate interplay between transcription factors and their network of coregulatory proteins taking place at the chromatin is gradually being revealed.

\section{Pioneer factors as mediator of lineage- specific transcriptional programs}

The FKH motif is an additional motif highly enriched in both ER $\alpha$ and AR cistromes (Carroll et al. 2005, 2006, Laganiere et al. 2005, Wang et al. 2007). The forkhead family member FoxA1 (HNF3 $\alpha$ ) is a key partner for $\mathrm{ER} \alpha$ and $\mathrm{AR}$ transcriptional activity in breast and prostate cancer respectively, recognizing the FKH motif. It was first characterized as a pioneer factor in liver tissue (Gualdi et al. 1996, Cirillo et al. 1998, Bossard \& Zaret 2000). More recently, its ATPindependent chromatin-remodeling activity, distinguishing it from the classical SWI/SNF complex, has shown to be central for ER $\alpha$ recruitment in breast cancer cells (Carroll et al. 2005, Laganiere et al. 2005, Eeckhoute et al. 2006), while it was found to physically interact with AR in prostate cancer cells (Gao et al. 2003, Wang et al. 2007). Present on the chromatin at the basal state, FoxA1 is found at more than $60 \%$ of ER $\alpha$ - and AR-binding sites driving the transcriptional response in breast and prostate cancer cells respectively (Lupien et al. 2008). In fact, through its chromatin-remodeling activity, FoxA1 allows for the opening of specific genomic regions in the absence of hormone (Carroll et al. 2005, Laganiere et al. 2005, Eeckhoute et al. 2006). Hence, under hormonal stimulation, ER $\alpha$ and AR are recruited to FoxA1 sites harboring permissive sequences such as EREs and AREs (Lupien et al. 2008, Fig. 3). In accordance with its predominant role in ER $\alpha$ signaling, FoxA1 is 


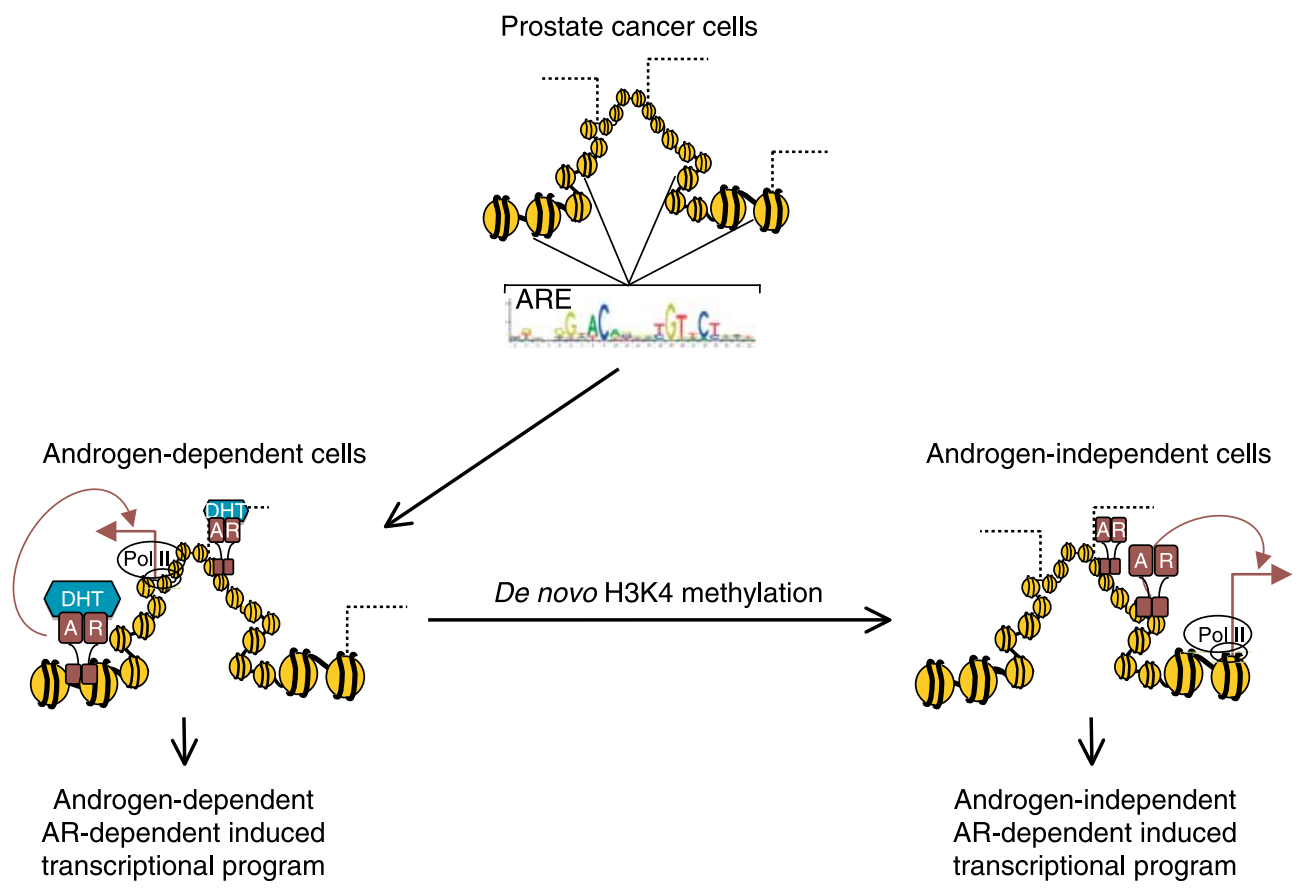

Figure 2 Chromatin architecture reprogramming in castration-resistant prostate cancer cells. Similar to ER $\alpha$ in breast cancer cell lines, AR is recruited to a fraction of its putative binding sites in androgen-dependent prostate cancer cells. In castration-resistant prostate cancer cells, the genome-wide AR recruitment pattern is altered. This is dependent on the reprogramming of the chromatin architecture typified by de novo methylation of lysine 4 on histone $\mathrm{H} 3$ (H3K4me).

typically highly expressed in ER $\alpha$-positive primary breast tumors and is an important marker of breast cancer subtype and prognosis (Habashy et al. 2008, Thorat et al. 2008). FoxA1 is also highly expressed in prostate cancer where it is believed to contribute to the establishment of specific gene expression programs (Mirosevich et al. 2006). However, the comparison of FoxA1 cistromes between breast and prostate cancer cells reveals its cell-type-specific recruitment (Lupien et al. 2008). Indeed, less than $40 \%$ of FoxA1-binding sites are shared between these two cell lines supporting the notion that FoxA1 is recruited in a lineage-specific fashion. Importantly, because FoxA1 guides the recruitment of transcription factors, such as ER $\alpha$ and AR, lineage-specific transcriptional programs dependent on these transcription factors are directly affected by FoxA1's cell-type-specific recruitment (Fig. 3).

\section{Epigenetic signatures define lineage- specific functional regulatory elements}

The requirement for lineage-specific recruitment of the pioneer factor FoxA1 highlights the importance of understanding how such differential recruitment takes place. Recently, specific epigenetic signatures distinguishing non-promoter from promoter-regulatory elements have been reported (Santos-Rosa et al. 2002, Ng et al. 2003, Schneider et al. 2004, Schubeler et al. 2004, Bernstein et al. 2005, Pokholok et al. 2005, Heintzman et al. 2007). This signature, characterized by different methylation states (mono-, di-, or tri-) of lysine 4 on histone H3 (H3K4me1, me2, or me3), was also found associated with distinct chromatin regions permissive for transgene expression (Yan \& Boyd 2006). Specifically, H3K4me1 and H3K4me2 were associated with non-promoter-regulatory elements, while $\mathrm{H} 3 \mathrm{~K} 4 \mathrm{me} 3$ was found at promoter regions (Heintzman et al. 2007). Furthermore, regions enriched in $\mathrm{H} 3 \mathrm{~K} 4 \mathrm{me} 2$ or me3 associate with DNase I hypersensitivity, a marker of active-regulatory regions (Xi et al. 2007). Therefore, this supports the notion that $\mathrm{H} 3 \mathrm{~K} 4 \mathrm{me} 2$ and H3K4me3 are specific for functional non-promoter and promoter-regulatory elements respectively.

In agreement, the cell-type-specific cistromes for the pioneer factor FoxA1 in breast and prostate cancer cells are dependent on $\mathrm{H} 3 \mathrm{~K} 4 \mathrm{me} 1 / \mathrm{me} 2$ distribution (Lupien et al. 2008). In reality, H3K4me1/me2 defines in a lineage-specific manner through which regulatory elements are able to recruit FoxA1 (Fig. 3). Indeed, removal of this epigenetic signature through overexpression of the lysine demethylase KDM1/LSD1 


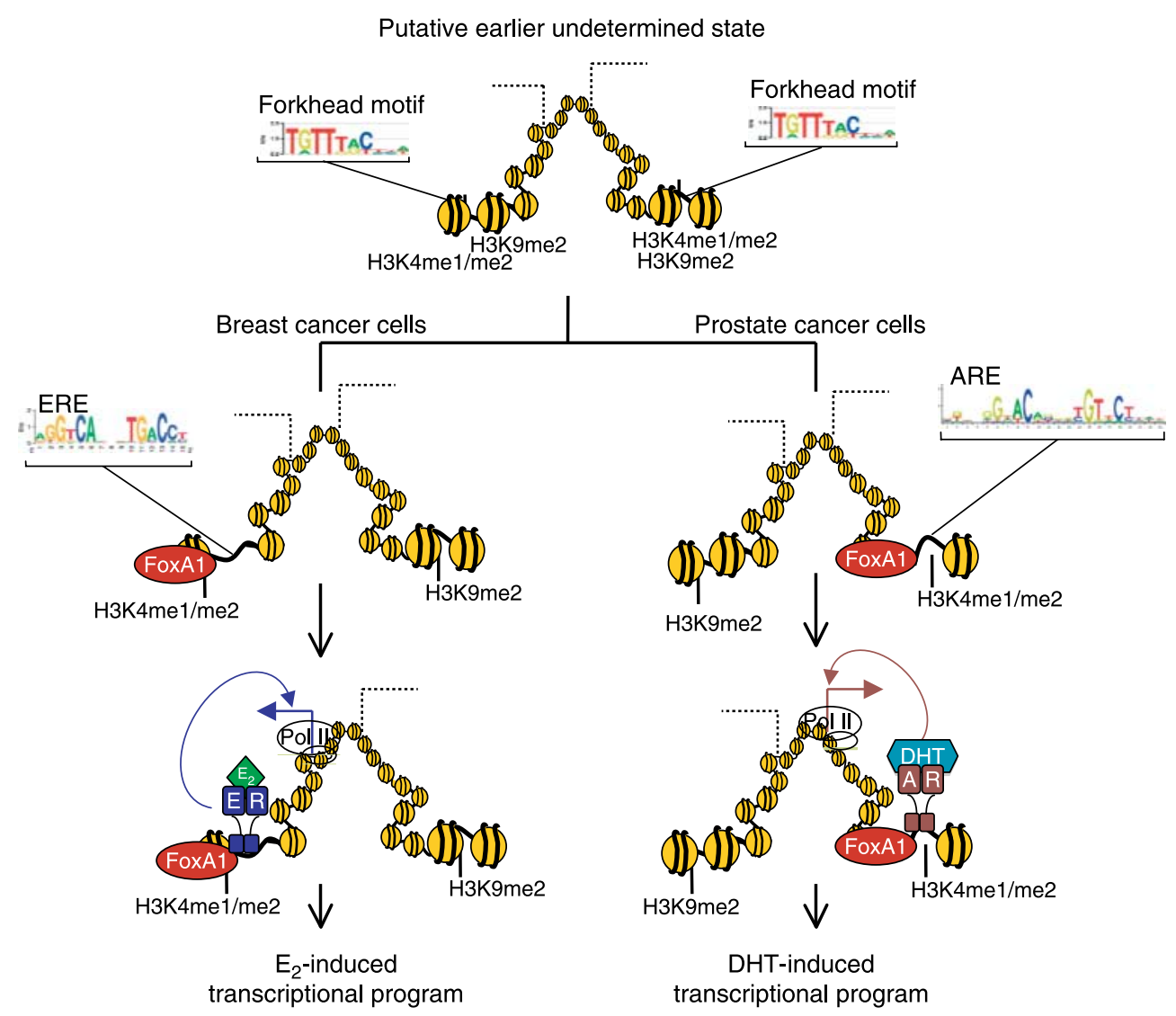

Figure 3 Lineage-specific distribution of histone H3 methylation on lysine 4 guides FoxA1 recruitment. Differentiated cells are characterized by a unique distribution of epigenetic marks. FoxA1 will specifically be recruited to genomic regions harboring the forkhead motif $(\mathrm{FKH})$ marked by H3K4me1/me2. Through its chromatin-remodeling activity, neighboring chromatin will be further opened and accessible to other transcription factors such as $E R \alpha$ and $A R$ in breast and prostate cancer cells respectively. By contrast, $\mathrm{FKH}$ regions lacking $\mathrm{H} 3 \mathrm{~K} 4 \mathrm{me} 1 / \mathrm{me} 2$ will typically associate with $\mathrm{H} 3 \mathrm{~K} 9 \mathrm{me} 2$ and be deprived of FoxA1 recruitment. Hence, the lineage-specific distribution of $\mathrm{H} 3 \mathrm{~K} 4 \mathrm{me} 1 / \mathrm{me} 2$ and $\mathrm{H} 3 \mathrm{~K} 9 \mathrm{me} 2$ guides FoxA1 binding, which in turn restricts the recruitment of other transcription factors.

prevents FoxA1 recruitment (Lupien et al. 2008, Wang et al. 2009). This signature is also characteristic of the $\mathrm{ER} \alpha$ cistrome not overlapping with FoxA1 (M L and M B unpublished data). In fact, lineage-specific ER $\alpha$ cistromes correlate with the H3K4me1/me2 distribution. Indeed, ER $\alpha$-binding sites specific to breast cancer or osteosarcoma cells relate to the unique distribution of $\mathrm{H} 3 \mathrm{~K} 4 \mathrm{me} 1 / \mathrm{me} 2$ in these respective cell lines, regardless of FoxA1 status (Krum et al. 2008). Similarly, the recruitment of AR to novel sites in castration-resistant prostate cancer cells is dependent on the de novo $\mathrm{H} 3 \mathrm{~K} 4$ mono- and dimethylation (Wang et al. 2009). Removal of H3K4 mono- and dimethylation through KDM1 overexpression in this model also suppressed FoxA1 and AR recruitment (Wang et al. 2009).

Similar to the role of FoxA1 as a pioneer factor that translates the $\mathrm{H} 3 \mathrm{~K} 4 \mathrm{me} 1 / \mathrm{me} 2$ signature at non-promoterregulatory elements, specific chromatin-remodeling components are recruited to $\mathrm{H} 3 \mathrm{~K} 4 \mathrm{me} 3$-marked promoters. The ATP-dependent chromatin-remodeling enzyme CHD1 and the ATPase SNF2H are recruited to H3K4-methylated promoters (Santos-Rosa et al. 2003, Flanagan et al. 2005, Sims et al. 2005). This suggests that epigenetic marks are insufficient for transcription factor recruitment. Therefore, it appears that the interplay between epigenetic marks and chromatin-remodeling factors is required to open chromatin in specific genomic locations to guide transcription factor recruitment both at promoter and non-promoter-regulatory elements.

Understanding how the epigenetic signatures, such as the methylated-H3K4-based signature, are established in the course of normal and disease development is of central interest. To date, up to ten histone methyltransferases specific to $\mathrm{H} 3 \mathrm{~K} 4$ have been characterized and a growing number of histone demethylases are being identified (Christensen et al. 2007, Eissenberg et al. 2007, Iwase et al. 2007, 
Klose et al. 2007, Lee et al. 2007, Ruthenburg et al. 2007, Seward et al. 2007, Shi \& Whetstine 2007, Tahiliani et al. 2007, Yamane et al. 2007). Therefore, the methylation state of H3K4 appears to be under tight regulation. Previous reports have indicated that the distribution of $\mathrm{H} 3 \mathrm{~K} 4 \mathrm{me} 2$ is established early during differentiation (Chambeyron \& Bickmore 2004). Similarly, work on promoter regions has revealed a progression from a broad to a more restricted distribution for $\mathrm{H} 3 \mathrm{~K} 4 \mathrm{me} 3$ in the course of differentiation (Guenther et al. 2007, Mikkelsen et al. 2007). Interestingly, the bivalent state of histone modifications found at promoters relates to the transitional state of poised to active or repressed promoters. Indeed, in the course of differentiation, promoters harboring both $\mathrm{H} 3 \mathrm{~K} 4 \mathrm{me} 3$ and $\mathrm{H} 3 \mathrm{~K} 27 \mathrm{me} 3$ are enriched for $\mathrm{H} 3 \mathrm{~K} 4 \mathrm{me} 3$ when the associated genes are expressed and for H3K27me3 when the genes are silenced (Azuara et al. 2006, Bernstein et al. 2006, Guenther et al. 2007, Mikkelsen et al. 2007). Although there is no clear indication of a similar signature at nonpromoter-regulatory elements, $\mathrm{H} 3 \mathrm{~K} 9 \mathrm{me} 2$ has recently been found enriched at inaccessible promoter-distant regulatory elements (Lupien et al. 2008). Furthermore, $\mathrm{H} 3 \mathrm{~K} 4 \mathrm{me} 1 / \mathrm{me} 2$ and $\mathrm{H} 3 \mathrm{~K} 9 \mathrm{me} 2$ occurred together on more condensed FoxA1-binding sites as defined by DNaseI hypersensitivity and Formaldehyde-Assisted Isolation of Regulatory Elements, an additional method that delineates DNA accessibility (Giresi et al. 2007, Eeckhoute et al. 2009). Therefore, additional studies are needed to reveal fundamental components of the role played by chromatin structure in transcriptional regulation as well as the contribution transcriptional events may have on epigenetic components.

\section{Conclusion}

The wealth of information derived from cistromebased studies is already revealing core concepts of transcriptional regulation. Recently, a predictive model based on the ER $\alpha$ and FoxA1 cistromes from breast cancer cells as well as the cistrome of the insulator protein CCCTC-binding factor (CTCF) has predicted up to $70 \%$ of estrogen-regulated genes (Chan \& Song 2008). Pursuing this analysis to coregulatory factors and epigenetic components should reveal intricate mechanisms fine tuning the actions of ER $\alpha$ and AR. Considering the increasingly recognized role of epigenetic components in cancer development and progression, a better understanding of their function in transcriptional regulation will prove fundamental in the elaboration of novel therapeutic strategies to breast, prostate, and other cancers.

\section{Declaration of interest}

The authors declare that there is no conflict of interest that could be perceived as prejudicing the impartiality of the research reported.

\section{Funding}

This work was supported by grants from the NIDDK (R01DK074967 to M B), the NCI (P01 CA8011105, the DF/HCC Breast Cancer SPORE Grant, and the DF/HCC Prostate Cancer SPORE Grant to $\mathrm{M} \mathrm{B}$ ), and the US Department of Defense Breast Cancer Research Program Awards (W81XWH-08-1-0214 to M L).

\section{Acknowledgements}

We thank Drs J Eeckhoute, S T Bailey, M Ni, Q Wang, and $\mathrm{G}$ Morinville for their helpful discussion and critical reading of the manuscript.

\section{References}

Azuara V, Perry P, Sauer S, Spivakov M, Jorgensen HF, John RM, Gouti M, Casanova M, Warnes G, Merkenschlager M et al. 2006 Chromatin signatures of pluripotent cell lines. Nature Cell Biology 8 532-538.

Balk SP, Ko YJ \& Bubley GJ 2003 Biology of prostatespecific antigen. Journal of Clinical Oncology 21 383-391.

Bernstein BE, Kamal M, Lindblad-Toh K, Bekiranov S, Bailey DK, Huebert DJ, McMahon S, Karlsson EK, Kulbokas EJ III, Gingeras TR et al. 2005 Genomic maps and comparative analysis of histone modifications in human and mouse. Cell 120 169-181.

Bernstein BE, Mikkelsen TS, Xie X, Kamal M, Huebert DJ, Cuff J, Fry B, Meissner A, Wernig M, Plath K et al. 2006 A bivalent chromatin structure marks key developmental genes in embryonic stem cells. Cell 125 315-326.

Bhat-Nakshatri P, Wang G, Appaiah H, Luktuke N, Carroll JS, Geistlinger TR, Brown M, Badve S, Liu Y \& Nakshatri H 2008 AKT alters genome-wide estrogen receptor $\{\alpha\}$ binding and impacts estrogen signaling in breast cancer. Molecular and Cellular Biology 28 7487-7503.

Bieda M, Xu X, Singer MA, Green R \& Farnham PJ 2006 Unbiased location analysis of E2F1-binding sites suggests a widespread role for E2F1 in the human genome. Genome Research 16 595-605.

Bossard P \& Zaret KS 2000 Repressive and restrictive mesodermal interactions with gut endoderm: possible relation to Meckel's diverticulum. Development 127 4915-4923.

Carroll JS, Liu XS, Brodsky AS, Li W, Meyer CA, Szary AJ, Eeckhoute J, Shao W, Hestermann EV, Geistlinger TR et al. 2005 Chromosome-wide mapping of estrogen receptor binding reveals long-range regulation requiring the forkhead protein FoxA1. Cell 122 33-43. 
Carroll JS, Meyer CA, Song J, Li W, Geistlinger TR, Eeckhoute J, Brodsky AS, Keeton EK, Fertuck KC, Hall GF et al. 2006 Genome-wide analysis of estrogen receptor binding sites. Nature Genetics 38 1289-1297.

Chambeyron S \& Bickmore WA 2004 Chromatin decondensation and nuclear reorganization of the HoxB locus upon induction of transcription. Genes and Development 18 1119-1130.

Chan CS \& Song JS 2008 CCCTC-binding factor confines the distal action of estrogen receptor. Cancer Research $\mathbf{6 8}$ 9041-9049.

Christensen J, Agger K, Cloos PA, Pasini D, Rose S, Sennels L, Rappsilber J, Hansen KH, Salcini AE \& Helin K 2007 RBP2 belongs to a family of demethylases, specific for tri-and dimethylated lysine 4 on histone 3. Cell 128 1063-1076.

Cicatiello L, Addeo R, Sasso A, Altucci L, Petrizzi VB, Borgo R, Cancemi M, Caporali S, Caristi S, Scafoglio C et al. 2004 Estrogens and progesterone promote persistent CCND1 gene activation during G1 by inducing transcriptional derepression via c-Jun/c-Fos/estrogen receptor (progesterone receptor) complex assembly to a distal regulatory element and recruitment of cyclin D1 to its own gene promoter. Molecular and Cellular Biology 24 7260-7274.

Cirillo LA, McPherson CE, Bossard P, Stevens K, Cherian S, Shim EY, Clark KL, Burley SK \& Zaret KS 1998 Binding of the winged-helix transcription factor HNF3 to a linker histone site on the nucleosome. EMBO Journal 17 244-254.

Dekker J 2008 Gene regulation in the third dimension. Science 319 1793-1794.

Demichelis F \& Rubin MA 2007 TMPRSS2-ETS fusion prostate cancer: biological and clinical implications. Journal of Clinical Pathology 60 1185-1186.

Deschenes J, Bourdeau V, White JH \& Mader S 2007 Regulation of GREB1 transcription by estrogen receptor alpha through a multipartite enhancer spread over $20 \mathrm{~kb}$ of upstream flanking sequences. Journal of Biological Chemistry 282 17335-17339.

Eeckhoute J, Carroll JS, Geistlinger TR, Torres-Arzayus MI \& Brown M 2006 A cell-type-specific transcriptional network required for estrogen regulation of cyclin D1 and cell cycle progression in breast cancer. Genes and Development 20 2513-2526.

Eeckhoute J, Keeton EK, Lupien M, Krum SA, Carroll JS \& Brown M 2007 Positive cross-regulatory loop ties GATA3 to estrogen receptor alpha expression in breast cancer. Cancer Research 67 6477-6483.

Eeckhoute J, Lupien M, Meyer C, Verzi M, Shivdasani R, Liu XS \& Brown M 2009 Cell-type selective chromatin remodeling defines the active subset of FoxA1-bound enhancers. Genome Research 19 372-380.

Eissenberg JC, Lee MG, Schneider J, Ilvarsonn A, Shiekhattar R \& Shilatifard A 2007 The trithorax-group gene in Drosophila little imaginal discs encodes a trimethylated histone H3 Lys4 demethylase. Nature Structural \& Molecular Biology 14 344-346.
Flanagan JF, Mi LZ, Chruszcz M, Cymborowski M, Clines KL, Kim Y, Minor W, Rastinejad F \& Khorasanizadeh S 2005 Double chromodomains cooperate to recognize the methylated histone H3 tail. Nature 438 1181-1185.

Frietze S, Lupien M, Silver PA \& Brown M 2008 CARM1 regulates estrogen-stimulated breast cancer growth through up-regulation of E2F1. Cancer Research 68 301-306.

Gao N, Zhang J, Rao MA, Case TC, Mirosevich J, Wang Y, Jin R, Gupta A, Rennie PS \& Matusik RJ 2003

The role of hepatocyte nuclear factor-3 alpha (forkhead box A1) and androgen receptor in transcriptional regulation of prostatic genes. Molecular Endocrinology 17 1484-1507.

Giresi PG, Kim J, McDaniell RM, Iyer VR \& Lieb JD 2007 FAIRE (form, maldehyde-assisted isolation of regulatory elements) isolates active regulatory elements from human chromatin. Genome Research 17 877-885.

Gonzalez MI \& Robins DM 2001 Oct-1 preferentially interacts with androgen receptor in a DNA-dependent manner that facilitates recruitment of SRC-1. Journal of Biological Chemistry 276 6420-6428.

Green KA \& Carroll JS 2007 Oestrogen-receptor-mediated transcription and the influence of co-factors and chromatin state. Nature Reviews. Cancer 7 713-722.

Gualdi R, Bossard P, Zheng M, Hamada Y, Coleman JR \& Zaret KS 1996 Hepatic specification of the gut endoderm in vitro: cell signaling and transcriptional control. Genes and Development 10 1670-1682.

Guenther MG, Levine SS, Boyer LA, Jaenisch R \& Young RA 2007 A chromatin landmark and transcription initiation at most promoters in human cells. Cell 130 77-88.

Habashy HO, Powe DG, Rakha EA, Ball G, Paish C, Gee J, Nicholson RI \& Ellis IO 2008 Forkhead-box A1 (FOXA1) expression in breast cancer and its prognostic significance. European Journal of Cancer 44 1541-1551.

Heinlein CA \& Chang C 2004 Androgen receptor in prostate cancer. Endocrine Reviews 25 276-308.

Heintzman ND, Stuart RK, Hon G, Fu Y, Ching CW, Hawkins RD, Barrera LO, Van Calcar S, Qu C, Ching KA et al. 2007 Distinct and predictive chromatin signatures of transcriptional promoters and enhancers in the human genome. Nature Genetics 39 311-318.

Holmes KA, Song JS, Liu XS, Brown M \& Carroll JS 2008 Nkx3-1 and LEF-1 function as transcriptional inhibitors of estrogen receptor activity. Cancer Research 68 7380-7385.

Hua S, Kallen CB, Dhar R, Baquero MT, Mason CE, Russell BA, Shah PK, Liu J, Khramtsov A, Tretiakova MS et al. 2008 Genomic analysis of estrogen cascade reveals histone variant H2A.Z associated with breast cancer progression. Molecular Systems Biology 4188.

Hurtado A, Holmes KA, Geistlinger TR, Hutcheson IR, Nicholson RI, Brown M, Jiang J, Howat WJ, Ali S \& Carroll JS 2008 Regulation of ERBB2 by oestrogen receptor-PAX2 determines response to tamoxifen. Nature $456663-666$. 
Iwase S, Lan F, Bayliss P, de la Torre-Ubieta L, Huarte M, Qi HH, Whetstine JR, Bonni A, Roberts TM \& Shi Y 2007 The X-linked mental retardation gene SMCX/ JARID1C defines a family of histone H3 lysine 4 demethylases. Cell 128 1077-1088.

Johnson DS, Mortazavi A, Myers RM \& Wold B 2007 Genome-wide mapping of in vivo protein-DNA interactions. Science 316 1497-1502.

Klose RJ, Yan Q, Tothova Z, Yamane K, ErdjumentBromage H, Tempst P, Gilliland DG, Zhang Y \& Kaelin WG Jr 2007 The retinoblastoma binding protein RBP2 is an H3K4 demethylase. Cell 128 889-900.

Krum SA, Miranda-Carboni GA, Lupien M, Eeckhoute J, Carroll JS \& Brown M 2008 Unique ER $\{\alpha\}$ cistromes control cell type-specific gene regulation. Molecular Endocrinology 22 2393-2406.

Laganiere J, Deblois G, Lefebvre C, Bataille AR, Robert F \& Giguere V 2005 Location analysis of estrogen receptor alpha target promoters reveals that FOXA1 defines a domain of the estrogen response. PNAS $\mathbf{1 0 2}$ 11651-11656.

Lapointe J, Li C, Higgins JP, van de Rijn M, Bair E, Montgomery K, Ferrari M, Egevad L, Rayford W, Bergerheim U et al. 2004 Gene expression profiling identifies clinically relevant subtypes of prostate cancer. PNAS 101 811-816.

Lee N, Zhang J, Klose RJ, Erdjument-Bromage H, Tempst P, Jones RS \& Zhang Y 2007 The trithorax-group protein Lid is a histone H3 trimethyl-Lys4 demethylase. Nature Structural \& Molecular Biology 14 341-343.

Lim CA, Yao F, Wong JJ, George J, Xu H, Chiu KP, Sung WK, Lipovich L, Vega VB, Chen J et al. 2007 Genome-wide mapping of RELA(p65) binding identifies E2F1 as a transcriptional activator recruited by NF-kappaB upon TLR4 activation. Molecular Cell 27 622-635.

Lin CY, Vega VB, Thomsen JS, Zhang T, Kong SL, Xie M, Chiu KP, Lipovich L, Barnett DH, Stossi F et al. 2007 Whole-genome cartography of estrogen receptor alpha binding sites. PLoS Genetics 3 e87.

Liu Y, Gao H, Marstrand TT, Strom A, Valen E, Sandelin A, Gustafsson JA \& Dahlman-Wright K 2008 The genome landscape of $\operatorname{ER}\{\alpha\}$ - and $\operatorname{ER}\{\beta\}$-binding DNA regions. PNAS 105 2604-2609.

Lupien M, Eeckhoute J, Meyer C, Wang Q, Zhang Y, Li W, Carroll J, Liu X \& Brown M 2008 FoxA1 translates epigenetic signatures into enhancer driven lineagespecific transcription. Cell 132 958-970.

Mikkelsen TS, Ku M, Jaffe DB, Issac B, Lieberman E, Giannoukos G, Alvarez P, Brockman W, Kim TK, Koche RP et al. 2007 Genome-wide maps of chromatin state in pluripotent and lineage-committed cells. Nature 448 553-560.

Mirosevich J, Gao N, Gupta A, Shappell SB, Jove R \& Matusik RJ 2006 Expression and role of Foxa proteins in prostate cancer. Prostate 66 1013-1028.
Ng HH, Robert F, Young RA \& Struhl K 2003 Targeted recruitment of Set1 histone methylase by elongating Pol II provides a localized mark and memory of recent transcriptional activity. Molecular Cell 11 709-719.

Perez-Stable CM, Pozas A \& Roos BA 2000 A role for GATA transcription factors in the androgen regulation of the prostate-specific antigen gene enhancer. Molecular and Cellular Endocrinology 167 43-53.

Pokholok DK, Harbison CT, Levine S, Cole M, Hannett NM, Lee TI, Bell GW, Walker K, Rolfe PA, Herbolsheimer E et al. 2005 Genome-wide map of nucleosome acetylation and methylation in yeast. Cell 122 517-527.

Prall OW, Rogan EM, Musgrove EA, Watts CK \& Sutherland RL 1998 c-Myc or cyclin D1 mimics estrogen effects on cyclin E-Cdk2 activation and cell cycle reentry. Molecular and Cellular Biology 18 4499-4508.

Ruthenburg AJ, Allis CD \& Wysocka J 2007 Methylation of lysine 4 on histone $\mathrm{H} 3$ : intricacy of writing and reading a single epigenetic mark. Molecular Cell 25 15-30.

Sanchez R, Nguyen D, Rocha W, White JH \& Mader S 2002 Diversity in the mechanisms of gene regulation by estrogen receptors. Bioessays 24 244-254.

Santos-Rosa H, Schneider R, Bannister AJ, Sherriff J, Bernstein BE, Emre NC, Schreiber SL, Mellor J \& Kouzarides T 2002 Active genes are tri-methylated at K4 of histone H3. Nature 419 407-411.

Santos-Rosa H, Schneider R, Bernstein BE, Karabetsou N, Morillon A, Weise C, Schreiber SL, Mellor J \& Kouzarides T 2003 Methylation of histone H3 K4 mediates association of the Isw1p ATPase with chromatin. Molecular Cell 12 1325-1332.

Schneider R, Bannister AJ, Myers FA, Thorne AW, Crane-Robinson C \& Kouzarides T 2004 Histone H3 lysine 4 methylation patterns in higher eukaryotic genes. Nature Cell Biology 6 73-77.

Schubeler D, MacAlpine DM, Scalzo D, Wirbelauer C, Kooperberg C, van Leeuwen F, Gottschling DE, O'Neill LP, Turner BM, Delrow J et al. 2004 The histone modification pattern of active genes revealed through genome-wide chromatin analysis of a higher eukaryote. Genes and Development 18 1263-1271.

Setlur SR, Mertz KD, Hoshida Y, Demichelis F, Lupien M, Perner S, Sboner A, Pawitan Y, Andren O, Johnson LA et al. 2008 Estrogen-dependent signaling in a molecularly distinct subclass of aggressive prostate cancer. Journal of the National Cancer Institute 100 815-825. Seward DJ, Cubberley G, Kim S, Schonewald M, Zhang L, Tripet B \& Bentley DL 2007 Demethylation of trimethylated histone H3 Lys4 in vivo by JARID1 JmjC proteins. Nature Structural \& Molecular Biology 14 240-242.

Shi Y \& Whetstine JR 2007 Dynamic regulation of histone lysine methylation by demethylases. Molecular Cell 25 1-14.

Sims RJ III, Chen CF, Santos-Rosa H, Kouzarides T, Patel SS \& Reinberg D 2005 Human but not yeast CHD1 binds 
directly and selectively to histone $\mathrm{H} 3$ methylated at lysine 4 via its tandem chromodomains. Journal of Biological Chemistry 280 41789-41792.

Sorlie T, Perou CM, Tibshirani R, Aas T, Geisler S, Johnsen H, Hastie T, Eisen MB, van de Rijn M, Jeffrey SS et al. 2001 Gene expression patterns of breast carcinomas distinguish tumor subclasses with clinical implications. PNAS 98 10869-10874.

Sorlie T, Tibshirani R, Parker J, Hastie T, Marron JS, Nobel A, Deng S, Johnsen H, Pesich R, Geisler S et al. 2003 Repeated observation of breast tumor subtypes in independent gene expression data sets. PNAS 100 8418-8423.

Stender JD, Frasor J, Komm B, Chang KC, Kraus WL \& Katzenellenbogen BS 2007 Estrogen-regulated gene networks in human breast cancer cells: involvement of E2F1 in the regulation of cell proliferation. Molecular Endocrinology 21 2112-2123.

Tahiliani M, Mei P, Fang R, Leonor T, Rutenberg M, Shimizu F, Li J, Rao A \& Shi Y 2007 The histone H3K4 demethylase SMCX links REST target genes to X-linked mental retardation. Nature 447 601-605.

Thorat MA, Marchio C, Morimiya A, Savage K, Nakshatri H, Reis-Filho JS \& Badve S 2008 Forkhead box A1 expression in breast cancer is associated with luminal subtype and good prognosis. Journal of Clinical Pathology 61 327-332.

Valouev A, Johnson DS, Sundquist A, Medina C, Anton E, Batzoglou S, Myers RM \& Sidow A 2008 Genome-wide analysis of transcription factor binding sites based on ChIP-Seq data. Nature Methods 5 829-834.

Wang Q, Li W, Liu XS, Carroll JS, Janne OA, Keeton EK, Chinnaiyan AM, Pienta KJ \& Brown M 2007 A hierarchical network of transcription factors governs androgen recepor dependent prostate cancer growth. Molecular Cell 27 380-392.
Wang Q, Li W, Zhang Y, Yuan X, Xu K, Yu J, Beroukhim R, Wang H, Lupien M, Wu T et al. 2009 Androgen receptor regulates a distinct transcription program in androgenindependent prostate cancer. Cell [in press].

Welsh JB, Sapinoso LM, Su AI, Kern SG, Wang-Rodriguez J, Moskaluk CA, Frierson HF Jr \& Hampton GM 2001 Analysis of gene expression identifies candidate markers and pharmacological targets in prostate cancer. Cancer Research 61 5974-5978.

Xi H, Shulha HP, Lin JM, Vales TR, Fu Y, Bodine DM, McKay RD, Chenoweth JG, Tesar PJ, Furey TS et al. 2007 Identification and characterization of cell typespecific and ubiquitous chromatin regulatory structures in the human genome. PLoS Genetics 3 e136.

Xu X, Bieda M, Jin VX, Rabinovich A, Oberley MJ, Green R \& Farnham PJA 2007 A comprehensive ChIP-chip analysis of E2F1, E2F4, and E2F6 in normal and tumor cells reveals interchangeable roles of E2F family members. Genome Research 17 1550-1561.

Yamane K, Tateishi K, Klose RJ, Fang J, Fabrizio LA, Erdjument-Bromage H, Taylor-Papadimitriou J, Tempst P \& Zhang Y 2007 PLU-1 is an H3K4 demethylase involved in transcriptional repression and breast cancer cell proliferation. Molecular Cell $\mathbf{2 5}$ 801-812.

Yan C \& Boyd DD 2006 Histone H3 acetylation and H3 K4 methylation define distinct chromatin regions permissive for transgene expression. Molecular and Cellular Biology 26 6357-6371.

Yu YP, Landsittel D, Jing L, Nelson J, Ren B, Liu L, McDonald C, Thomas R, Dhir R, Finkelstein S et al. 2004 Gene expression alterations in prostate cancer predicting tumor aggression and preceding development of malignancy. Journal of Clinical Oncology 22 2790-2799. 